\title{
Serum Antibodies to Bovine Coronavirus in Swedish Sheep
}

\author{
By M. Tråvén ${ }^{1}$, U. Carlsson ${ }^{1}$, A. Lundén ${ }^{2}$ and B. Larsson ${ }^{3}$
}

\begin{abstract}
'Department of Ruminant Medicine and Veterinary Epidemiology, Section of Ruminant Medicine, the ${ }^{2}$ Department of Veterinary Microbiology, Section of Parasitology, Swedish University of Agricultural Sciences, Uppsala, and the ${ }^{3}$ Swedish Board of Agriculture, Jönköping, Sweden.
\end{abstract}

\begin{abstract}
Tråvén M, Carlsson U, Lundén A, Larsson B: Serum antibodies to bovine coronavirus in swedish sheep. Acta vet. scand. 1999, 40, 69-74. - Altogether 218 sheep sera from 40 flocks in different parts of Sweden were screened for antibodies to bovine coronavirus (BCV). Nineteen per cent of the sera were positive and there was a significantly higher frequency $(p<0.05)$ of at least one positive sample in flocks with more than 100 adult sheep than in smaller flocks. There was also a significantly higher frequency $(p<0.001)$ of positive samples from sheep older than 4 years than from younger ones. Only a weak relationship between BCV positivity ( 2 or more positive samples, $p<0.05$ ) and cattle contact was demonstrated in this study. Possible transmission routes and other factors that could have affected the result are discussed. In light of our finding that all 5 sheep experimentally exposed to BCV through contact with infectious cow faeces seroconverted, we conclude that the antibodies found in Swedish sheep are probably the result of $\mathrm{BCV}$ infections directly or indirectly transmitted from cattle.
\end{abstract}

survey; flock size; age; cattle contact; experimental infection; seroconversion.

\section{Introduction}

Bovine coronavirus $(\mathrm{BCV})$ has been shown to be involved in several disease syndromes: winter dysentery of adult cattle (Saif 1990, Alenius et al. 1991), calf diarrhoea (Stair et al. 1972, Mebus et al. 1973) and calf respiratory disease (Thomas et al. 1982, McNulty et al. 1984, Möstl \& Bürki 1987). The frequency of BCV infections in Swedish cattle is high, as concluded from reports of a $61 \% \mathrm{BCV}$ antibody prevalence in sera from Swedish heifers (Alenius et al. 1991) and $89 \%$ antibody positive bulk milk samples in a large survey of Swedish dairy herds (Tråvén et al. 1998). A $28.5 \%$ incidence of farmer-diagnosed winter dysentery during a one-year period in a region of central Sweden has also been reported (Tråvén et al. 1993).

Sheep and cattle are closely related species and naturally occurring cross-species transmission in both directions has been described for bovine virus diarrhoea virus (Carlsson 1991, Carlsson \& Belák 1994). Detection of antibodies reactive with $\mathrm{BCV}$ in sheep sera have been reported from Germany (Liebermann et al. 1986, Chengping 1985) and Japan (Sato et al. 1981) and electron microscopic findings of coronavirus-like particles in lamb faeces have been reported from Scotland (Snodgrass et al. 1980), Hungary (Nagy et al. 1983), Australia (Tzipori et al. 1978), New Zealand (Durham et al. 1979) and Chile (Reinhardt et al. 1995). In most of the studies very few samples were analysed and little information was given about the animals, such as age and how many flocks the samples originated from. Furthermore, none of these 
studies have tried to assess whether the particles were $\mathrm{BCV}$ or whether the serologic reactions were the result of $\mathrm{BCV}$ infections. Still, indications of coronavirus infections in sheep have been presented from countries with a distribution in accordance with the worldwide occurence of $\mathrm{BCV}$ infections.

The aim of this study was to determine if Swedish sheep have antibodies to BCV and, if so, to explore a possible link to cattle contact.

\section{Materials and methods \\ Samples}

Serum samples were collected during March to May by 11 local veterinarians in different parts of Sweden (Fig. 1). Five to 8 sheep were sampled per flock in 40 flocks, 202 ewes and 16 rams in all. Most of the sheep were of the Swedish Landrace. To increase the likelihood of finding seropositive animals, if present, older sheep were overrepresented in the study. The flock size varied between 15 and 720 sheep, with a median of 59 sheep, lambs not included. Direct contact between sheep and cattle during at least part of the year was reported by the farmer (Yes/No).

\section{Antibody detection}

Antibodies to BCV were detected in an indirect ELISA (Alenius et al. 1991). Sera were analysed in 1:10 dilution in duplicate wells with positive and negative bovine reference sera included on every plate. The optical density (OD) was determined at $450 \mathrm{~nm}$. A cut-off level of $2 \times$ the OD for the negative reference serum was used for each plate, varying between 0.25 and 0.35 . The specificity of sheep antibodies to $\mathrm{BCV}$ was tested in a virus neutralization (VN) test and a blocking ELISA. Based on the results from the indirect ELISA, 5 strongly positive (ODs $>1.20$ ), 3 weakly positive (ODs <0.40) and 4 negative sheep sera were selected for the

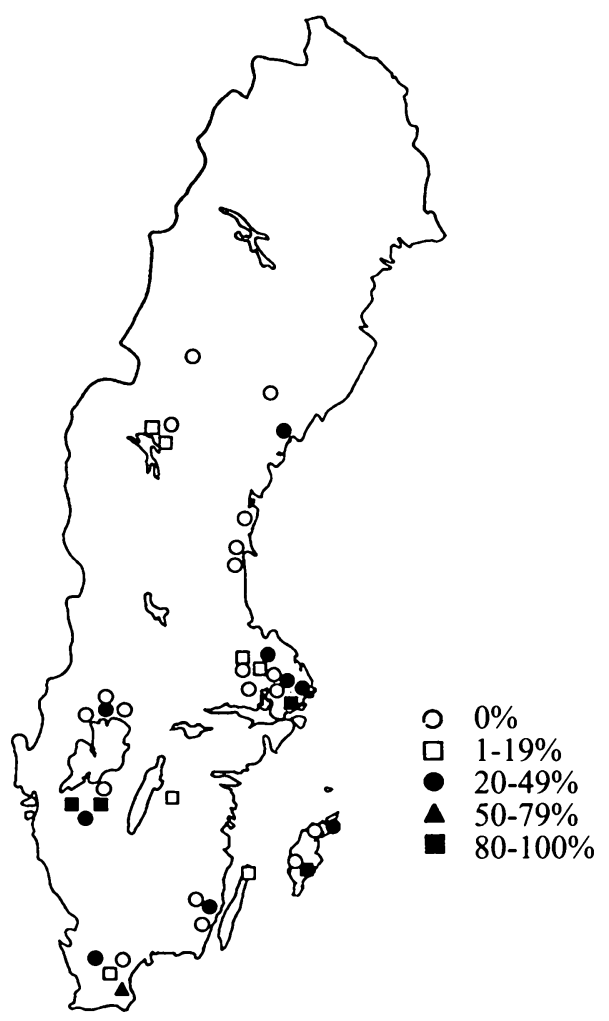

Figure 1. Location in Sweden of 40 sheep flocks tested for serum antibodies to bovine coronavirus. Five to 8 sheep were sampled per flock and the proportion of seropositive samples is shown.

$\mathrm{VN}$ and blocking tests. In the $\mathrm{VN}$ test sera were titrated by doubling dilution from $1: 2$ to $1: 256$ in microtitre plates. Otherwise the method was performed as described (Alenius et al. 1991). In the blocking assay, microtitre plates were coated with BCV antigen as described for the indirect ELISA. Serial dilutions (1:10, 25, 50, 250 and 1250) of the sheep sera along with the positive and negative bovine reference sera were added and the plates were incubated for one hour at $37^{\circ} \mathrm{C}$. After washings, a horseradish peroxidase-conjugated mouse anti-BCV monoclonal antibody was added and the procedure continued as described for the indirect 
ELISA. The blocking titre was determined as the highest serum dilution giving an OD below $50 \%$ of the negative reference serum OD.

\section{Experimental infection}

Five one- to two-year-old sheep, seronegative to $\mathrm{BCV}$, were brought in close contact with fresh faeces from a cow with acute winter dysentery. This cow was shown to have seroconverted to BCV 2 weeks later. About $200 \mathrm{ml}$ of infectious faeces was poured onto the bedding in the pen and all sheep had nose contact with the faeces. Sera were collected from the sheep before and 4 weeks after the day of contact with the infectious faeces.

\section{Statistical analyses}

Data were analysed in the $\chi^{2}$-test and Fischer's exact test.

\section{Results}

Of the 218 sheep sera, 42 (19.3\%) were positive to BCV (Table 1). The geographical location of the flocks and antibody prevalence is shown in Fig. 1. Twenty-three of the BCV antibody positive sera had high OD levels (over 0.80). Five strongly indirect ELISA-positive sheep sera from different flocks were confirmed to bind specifically to BCV in the blocking ELISA and to inhibit viral proliferation in the VN test. Titres are shown in Table 2. Four indirect ELISA-negative sera did not show blocking or neutralizing activity. Two of 3 weakly indirect ELISA-positive sera were VN positive but negative in the blocking ELISA. Indirect ELISA titres (doubling dilution from 1:10) were determined for these samples for comparison (Table 2).

Positive samples were found in 21 of the 40 flocks $(52.5 \%)$, and 12 of these had at least one reactor with an OD over 0.80 . In 4 flocks (10\%) more than $80 \%$ of the samples were positive. In 12 flocks, cattle and sheep were kept in contact. There was a significantly higher frequency $(62 \%)$ of contact with cattle in flocks with at least 2 positive sheep than in flocks with one or no positives $(23 \%, \mathrm{p}<0.05)$. However, the dif-

Table 1. Sheep flocks with 5-8 sheep tested for serum antibodies (ab) per flock. Flocks were divided into categories according to BCV antibody prevalence. Flocks having cattle contact and age of BCV-positive and negative sheep in each prevalence category are shown. Flocks with cattle on the farm, but without direct contact have been regarded as being without contact.

\begin{tabular}{|c|c|c|c|c|c|c|c|c|c|}
\hline \multirow{3}{*}{$\begin{array}{l}\text { Prevalence of } \\
\text { BCV ab positive } \\
\text { sheep (\%) }\end{array}$} & \multirow{3}{*}{$\begin{array}{l}\text { No. of } \\
\text { flocks }\end{array}$} & \multirow{2}{*}{\multicolumn{2}{|c|}{$\begin{array}{l}\text { Flocks with } \\
\text { cattle contact }\end{array}$}} & \multirow{2}{*}{\multicolumn{2}{|c|}{$\begin{array}{c}\text { No. of } \\
\text { samples }\end{array}$}} & \multicolumn{4}{|c|}{ No. of sheep with age (years) } \\
\hline & & & & & & \multicolumn{2}{|c|}{ ab pos. } & \multicolumn{2}{|c|}{ ab neg. } \\
\hline & & Yes & No & ab pos. & ab neg. & $\leq 4$ & $>4$ & $\leq 4$ & $>4$ \\
\hline 0 & $19^{a}$ & 6 & $11^{\mathrm{b}}$ & 0 & 99 & 0 & 0 & 77 & 22 \\
\hline $1-20$ & 13 & 1 & $12^{\mathrm{c}}$ & 13 & 60 & 8 & 5 & 51 & 9 \\
\hline $21-80$ & 4 & 3 & 1 & 9 & $16^{\mathrm{d}}$ & 5 & 4 & 14 & 1 \\
\hline $81-100$ & 4 & 2 & 2 & 20 & 1 & 9 & 11 & 0 & 1 \\
\hline Total & 40 & 12 & 26 & 42 & 176 & 22 & 20 & 142 & 33 \\
\hline
\end{tabular}

a Two flocks not reported if cattle contact.

b One flock with cattle on the farm, but not in direct contact with the sheep.

c Three flocks with cattle on the farm, but not in direct contact with the sheep.

d Age not reported in one of the BCV negative sheep.

Statistical results are shown in Results. 
Table 2. BCV antibody titres in sheep sera analysed in indirect ELISA, virus neutralisation test and blocking ELISA. All sheep came from different flocks.

\begin{tabular}{lcrc}
\hline Sheep ID & Indirect ELISA & VN test & Blocking ELISA \\
\hline 1056 & 160 & 64 & 10 \\
1102 & 320 & 128 & 50 \\
1198 & 640 & $\geq 256$ & 50 \\
1303 & 640 & 64 & 25 \\
1331 & 320 & 64 & 25 \\
1005 & 10 & 8 & $<10$ \\
1151 & 20 & 32 & $<10$ \\
1193 & 40 & $<8$ & $<10$ \\
1012 & $<10$ & $<8$ & $<10$ \\
1063 & $<10$ & $<8$ & $<10$ \\
1117 & $<10$ & $<8$ & $<10$ \\
1167 & $<10$ & $<8$ & $<10$ \\
\hline
\end{tabular}

ference between flocks with at least one, and flocks with no positive sample, was not significant ( $29 \%$ and $35 \%$, respectively).

In flocks larger than 100 sheep, there was also a significantly higher frequency of at least one positive sample $(83 \%$ and $39 \%$, respectively, $\mathrm{p}<0.05)$, and of at least 2 positives $(42 \%$ and $11 \%$, respectively, $\mathrm{p}<0.05)$ than in smaller flocks.

Sheep older than 4 years provided a significantly higher frequency $(65 \%)$ of positive samples than younger animals $(25 \%, \mathrm{p}<0.001$, negative flocks not included).

The $5 \mathrm{BCV}$ antibody negative sheep experimentally brought in contact with infectious faeces all had seroconverted to BCV 4 weeks after contact. Four of the sheep showed an antibody titre of 1:250 (ODs at 1:10 were 0.97-1.16) while one ewe only had a titre of 1:10 (OD 0.74 ) at 4 weeks.

\section{Discussion}

The prevalence of BCV seropositive sheep was $19.3 \%$ among the 218 sampled. This finding concurs with the sheep seroprevalence in 2 Ger- man studies of 16\% (Liebermann et al. 1986) and 22\% (Chengping 1985), respectively. VN tests were used in both these studies and titres, ranging from $1: 20$ to $\geq 1: 640$ and from 1:40 to $1: 320$, respectively, were comparable with our levels. However, the prevalence of BCV antibodies in the Swedish sheep population is probably lower than in our study. Older animals were over-represented since our aim was to find seroreactors, if present.

The possibility that the antibodies are the result of infections with a micro-organism strongly cross-reactive with BCV cannot be entirely excluded. The most likely cross-reactant in that case would be an ovine coronavirus, but so far ovine coronaviruses have not been described, to the authors' knowledge. Cross-species infection with BCV seems a more likely source of the sheep antibodies, since the experimental contact with $\mathrm{BCV}$ in this study showed that sheep are indeed able to mount an antibody response to BCV. Furthermore, the results from the blocking ELISA and the VN test confirm the BCV specificity of the positive sera tested. The occurrence of BCV transmission from cattle to sheep under field conditions is also indicated by the relationship between flocks with 2 or more seropositive sheep and contact with cattle. The nonsignificant difference in cattle contact between flocks with one or more BCV positive animals and flocks without seropositives may be due to some of the single reactors being introduced to the flock after they seroconverted to BCV. Unfortunately, no data on introduction of animals were available. Also, some flocks without cattle contact at the time of the study may have had contact a few years earlier, which was not recorded in the study. There is probably also a difference in risk for sheep $\mathrm{BCV}$ infection depending on whether the cattle contact occurs in the barn during the winter period or only on pasture, since winter dysentery outbreaks are quite rare during the pasture pe- 
riod (Tråvén et al. 1993). However, pasture or stable contact were not specified in our data. $\mathrm{BCV}$ transmission between cattle herds is suspected to be largely executed by indirect contacts like humans and equipment (Hedström \& Isaksson 1951, Roberts 1957, White et al. 1989). It is possible that indirect contacts can be involved also in the transmission of $\mathrm{BCV}$ from cattle to sheep flocks, resulting in a weak relationship between sheep BCV and direct cattle contact. If indirect contacts bring BCV to sheep flocks then transmission from sheep to sheep must occur to obtain an antibody prevalence over $80 \%$ as was found in 2 of the flocks without cattle contact. Experimental transmission of BCV directly from sheep to sheep or with sheep faeces has not been attempted to the authors' knowledge.

In the electron microscopic studies mentioned in the introduction most of the samples came from lambs with diarrhoea, but the association between $\mathrm{BCV}$ infection and clinical disease was not tested. Neither was our experimental infection planned to study the clinical outcome. However, the animals were attended daily and most of the group did not show obvious symptoms.

The finding that many of the seropositive animals were among the oldest sampled suggests that flocks get in contact with the virus at an interval of several years, provided that IgG titres can be maintained for years, such as after BCV infection (personal observations) and bovine respiratory syncytial virus infection (Elvander 1996) in cattle, and after border disease virus infection in sheep (Carlsson \& Belák 1994).

The significantly higher frequency of positive samples in flocks with more than 100 sheep than in smaller flocks, concurs with the finding in dairy herds of a relationship between herd size and both BCV antibody prevalence in bulk milk (Tråvén et al. 1998) and the incidence of winter dysentery (White et al. 1989).
The conclusions of this study are that Swedish sheep possess serum antibodies specific for $\mathrm{BCV}$ and that sheep experimentally exposed to $\mathrm{BCV}$ produce serum antibodies to the virus. Thus, the antibodies found in naturally infected sheep probably are the result of BCV infections transmitted directly or indirectly from cattle. Further studies are needed to examine whether $\mathrm{BCV}$ can be transmitted between sheep and if the infection is clinically important. Also, the question whether sheep can play an epidemiologic role in BCV outbreaks needs to be addressed.

\section{Acknowledgements}

Anette Silván is gratefully acknowledged for skilful laboratory work and Johan Höglund for graphical computer guidance. This study was supported by grants from the Farmers' Council for Research and Development.

\section{References}

Alenius $S$, Niskanen R, Juntti N, Larsson B: Bovine coronavirus as the causative agent of winter dysentery: serological evidence. Acta vet. scand. 1991, 32, 163-170.

Carlsson U: Border disease in sheep caused by transmission of virus from cattle persistently infected with bovine virus diarrhoea virus. Vet. Rec. 1991, 128, 145-147.

Carlsson U, Belák $K$ : Border disease virus transmitted to sheep and cattle by a persistently infected ewe: epidemiology and control. Acta vet. scand. 1994, 35, 79-88.

Chengping $L$ : Isolierung, Charakterisierung und Epizootiologie boviner Coronaviren. (Isolation, characterization and epidemiology of bovine coronavirus.). Vet. Med. Thesis, University of München, 1985. (In German).

Durham PJK, Stevenson BJ, Farquharson BC: Rotavirus and coronavirus associated diarrhoea in domestic animals. N.Z. vet. J. 1979, 27, 30-32.

Elvander M: Severe respiratory disease in dairy cows caused by infection with bovine respiratory syncytial virus. Vet. Rec. 1996, 138, 101-105. 
Hedström H, Isaksson A: Epizootic enteritis in cattle in Sweden. Cornell Vet. 1951, 42, 251-253.

Liebermann $H V$, Hille $G$, Herold $M$ : Coronavirus infections of sheep. Monatshefte Vet.-Med. 1986, 41, 814-815.

McNulty MS, Bryson DG, Allan GM, Logan EF: Coronavirus infection of the bovine respiratory tract. Vet. Microbiol. 1984, 9, 425-434.

Mebus CA, Stair EL, Rhodes MB, Twiehaus MJ: Pathology of neonatal calf diarrhea induced by a coronavirus-like agent. Vet. Path. 1973, 10, 4564.

Möstl $K V$, Bürki $F$ : Ursächliche Beteiligung boviner Coronaviren an respiratorischen Krankheitsausbrüchen bei Kälbern und pathologisch-immunologischer Überlegungen hierzu. (Bovine coronavirus in calf respiratory disease - pathological and immunological considerations.). Dt. tierärztl. Wschr. 1987, 95, 19-22. (In German).

Nagy B, Nagy G, Pálfi $V$, Bozsó M: Occurence of cryptosporidia, rotavirus, coronavirus-like particles and K99+ Escherichia Coli in goat kids and lambs. Proc. $3^{\text {rd }}$ Int. Symp. Vet. Lab. Diagn., Ames, Iowa, USA 1983, 2, 525-531.

Reinhardt G, Zamora J, Tadich N, Polette M, Aguilar $M$, Riedemann $S$, Palisson J: Diagnosis of coronavirus in sheep in Valdivia province, $\mathrm{X}$ region, Chile. Archos Med. vet., Chile 1995, 27, 129132.

Roberts $S J$ : Winter dysentery in dairy cattle. Cornell Vet. 1957, 47, 372-388.

Saif $L J$ : A review of evidence implicating bovine coronavirus in the etiology of winter dysentery in cows: an enigma resolved? Cornell Vet. 1990,80, 303-311.

Sato K, Inaba Y, Miura Y, Tokuhisa S, Akashi H, Shinozaki $T$, Matumoto $M$ : Neutralizing antibody to calf diarrhea coronavirus in various animal species in Japan. Microbiol. Immunol. 1981, 25, 623-625.

Snodgrass D, Herring J, Reid H, Scott F, Gray E: Virus infections in cattle and sheep in Scotland 1975-1978. Vet. Rec. 1980, 106, 193-195.

Stair EL, Rhodes $M B$, White $R G$, Mebus CA: Neonatal calf diarrhea: purification and electron mi- croscopy of a coronavirus-like agent. Am. J. vet. Res. 1972, 33, 1147-1156.

Thomas LH, Gourlay RN, Stott EJ, Howard CJ, Bridger JC: A search for new microorganisms in calf pneumonia by the inoculation of gnotobiotic calves. Res. vet. Sci. 1982, 33, 170-182.

Tråvén $M$, Björnerot L, Larsson B: Nation-wide survey of antibodies to bovine coronavirus in Swedish dairy herd bulk milk. Vet. Rec. in press.

Tråvén $M$, Sundberg $J$, Larsson $B$, Niskanen $R$ : Winter dysentery diagnosed by farmers in dairy herds in central Sweden: incidence, clinical signs and protective immunity. Vet. Rec. 1993, 133, 315 318.

Tzipori S, Smith M, Makin T, McCaughan C: Enteric coronavirus-like particles in sheep. Austr. vet. J. 1978, 54, 320-321.

White ME, Schukken YH, Tanksley B: Space-time clustering of, and risk factors for, farmer-diagnosed winter dysentery in dairy cattle. Can. vet. J. 1989, 30, 948-951.

\section{Sammanfattning}

Serumantikroppar mot bovint coronavirus hos svenska får.

Antikroppar mot bovint coronavirus (BCV) analyserades i serumprover från 218 får i 40 besättningar belägna i olika delar av Sverige. $19 \%$ av proverna var positiva med en signifikant högre frekvens av minst ett positivt prov från besättningar större än 100 vuxna făr än från mindre besättningar $(\mathrm{p}<0,05)$. En signifikant högre andel positiva prover sågs också hos făr äldre än 4 år än hos yngre får $(\mathrm{p}<0.001)$. Endast ett svagt samband kunde påvisas mellan BCV-positiva prover $\mathrm{i}$ besättningen (minst 2 positiva prover per besättning, $\mathrm{p}<0.05$ ) och direktkontakt med nötkreatur. Tänkbara smittvägar för BCV och andra förhållanden som kan ha påverkat resultatet diskuteras i artikeln. Samtliga fem BCV-seronegativa får som smittades experimentellt genom kontakt med BCV i ko-träck bildade antikroppar mot BCV. Därför är vår slutsats att de serumantikroppar som detekterats $\mathrm{i}$ svenska fårbesättningar troligen är orsakade av direkt eller indirekt $\mathrm{BCV}$-smitta från nötkreatur.

(Received August 11, 1998; accepted December 7, 1998).

Reprints may be obtained from: M. Tråvén, Department of Ruminant Medicine and Veterinary Epidemiology, Section of Ruminant Medicine, P.O. Box 7019, S-750 07 Uppsala, Sweden. E-mail: madelein.traven@idmed.slu.se, tel: $+46(0) 18671782$, fax: +46-(0)18673545. 